\title{
Papua's Vertical Conflict in 2019: Existence of Free Papua Movement and United Nations Response
}

\author{
Achmad Busrotun Nufus ${ }^{1 *}$, Sukron Mazid ${ }^{1}$, Novitasari ${ }^{1}$, Delfiyan Widiyanto ${ }^{1}$, \\ Yasnanto $^{1}$
}

${ }^{1}$ School Department of Indonesia Language and Literature Education, Universitas Tidar Magelang, Indonesia *Corresponding author. Email: busro@untidar.ac.id

\begin{abstract}
Conflict between Indonesia Government and separatist of Free Papua Movement (OPM) has become a spotlight of the World and Indonesia citizens. Begins with case of racism against Papua students in Surabaya, August 16, 2019, finally there were many riots in Papua. Some people were killed and injured in various areas, such as in Deiyai, Manokwari, Jayapura, Sorong, Timika, and Fakfak. Papua People who proIndependence fly the Kejora Star Flag, which is a symbol of the OPM, and demands independence from Indonesia. This study aims to explain how the condition of vertical conflict between Indonesia government and OPM, existence of OPM in 2019 and how International World View on Indonesia about Indonesia's policies towards OPM and Papua. The method used in this research is a literature review with heuristic steps, source criticism, and interpretation. The results showed that this Vertical Conflict occurred because of historical factors in the struggle of nation, Politics, Social Affairs, and Indonesia's policy towards Papua. this research is expected to be able to contribute to various parties involved in the conflict. Government should be more careful in making policies related to people of Papua, while OPM is able to know how the risks will be accepted if disintegration of nation occurs between Indonesia and Papua.
\end{abstract}

Keywords: Vertical Conflict, OPM, United Nations

\section{INTRODUCTION}

Label of Free Papua Movement or often known as OPM is name given by Indonesia Government to every organization or faction led by pro-West Papua, their aim is to separate themselves from Indonesia (NKRI). Various actions that have been taken by OPM are able to invite attention both domestically and abroad. The Papua independence movement from NKRI has flared up since the collapse of New Order era (end of President Soeharto's leadership) in 1998, and Free Papua Movement (OPM) has become a vital organization in fighting for Papua independence. Name of OPM became more popular at the time of rebellion in Manokwari region, Papua and other sporadic military-based insurgency actions in Irian Jaya region, Indonesia [1]. OPM comes with the aim of liberating Papua and annulling the results of the Act of free choice (PEPERA) which is considered to violate the New York Article 18 agreement. The result of New York agreement is PEPERA Consultative Council which was held in Jayapura without any consultation with councils throughout Papua. PEPERA was implemented by the United Nations in 1969 under the coordination of the United Nations Temporary Executive Authority (UNTEA) which is a temporary implementing agency from the United Nations that served as a supervisor of West Irian.
The OPM struggle was pursued through political and military channels during era Aser Demotekay's leadership in 1963 and Terianus Arongger in 1964. Political channels were aimed at gaining foreign support, while the military was pursued through armed activities in Irian Jaya region. Until now OPM has become vital Organization that seeks to separate Papua from Indonesia. Various steps taken by OPM have led to Vertical Conflict that has not been resolved between Indonesia and OPM.

In 2019, OPM Rebellion has again caught attention both domestically and abroad. Conflict develops not only between Indonesia Government and OPM but also between Government and People who Pro-Papua Free. Due to various discriminatory acts and racism experienced by Papua students in various regions in Indonesia such as Surabaya and Malang, it caused a lot of riots in the Papua region. This study explains how the condition of vertical conflicts between the Indonesia government and OPM, the existence of OPM in 2019 and how International World View of Indonesia Nation is related to its policies towards OPM and Papua.

\section{RESEARCH METHODS}

The research method used in this study is through literature review. Data collection is carried out through library research through books, mass media, journals or other supporting documents. The steps used are heuristics (search through written sources) source criticism (activities of selecting, researching, identifying, assessing, and also comparing data sources), and interpretation (interesting generalizations and terminology), namely by linking the facts we get with other facts. Data which collected are 
compiled and sorted to answer existing research questions while data analysis is using qualitative methods.

\section{RESULTS AND DISCUSSION}

\subsection{Kejora Star Flag}

Kejora Star flag is often regarded as identity of Papua Independence and is a form of separatism. However, many traditional leaders disagree if Kejora Star flag considered as a symbol that represents OPM, although on every July 1 (TPN-OPM birth day) there are many Kejora Star flag raising actions in Papua. Most of people of Papua who reject the Kejora Star flag as Identity of OPM, some people consider that Kejora Star flag is a Regional Symbol, Great Flag and Cultural Symbols for People of Papua.

Guided by Government Regulation of Indonesia, Number 77 of 2007, concerning Regional symbols, Law of Indonesia, Number 21 of 2001 [2], concerning Special Autonomy for the Province of Papua, and Government Regulation in Lieu of Indonesia Law, Number 1 of 2008, concerning Amendments to Law, Number 21 of 2001 [3], said that the Regional Symbol is Great Flag and Cultural Symbol for Grandeur of Papua identity, in form of Regional flags, and Regional songs, which are not used as symbols of sovereignty or merely reflect uniqueness of the Unitary State of Indonesia Republic.

Historically and politically, Kejora Star flag became a symbol of the formation of an independent Papua state, created through Dutch National Committee's Manifesto on 19 October 1961 along with 70 people from West Papua. Aside from the determination of Kejora Star flag as a Flag, manifesto also produced other decisions, namely song "Hai Tanahku Papua" as the national anthem, "Mambruk" Bird as symbol of State, and "One People One Soul" as Motto. Kejora Star flag first flew on 1 December 1961 in Holladia, accompanied by the song "Hai Tanah Papua" along with the song "Wilhelmus". Flag raising and singing the song of independence in West Papua was carried out continuously for approximately one week until start of United Nations Temporary Executive Authority (UNTEA) on October 1, 1962. UNTEA's task, i.e. [4].

a. Receive administration surrender of government which has by State of West Papua from Netherlands.

b. Organizing a stable government in West Papua for a certain period of time

c. Submit administration surrender of government which has by State of West Papua to Government of Indonesia. Now, In Indonesia, raising Kejora Star flag has been banned, and for people who fly it will be ensnared by the provisions of the Criminal Code article 106, article 107, or article 108 governing "Treason". Article 107 paragraph (1), for example, explains that acts of treason aimed at overthrowing a legitimate government will be punishable by imprisonment of up to 15 years.

Indonesia government guided by article 2 paragraph 1 of Law No. 21 of 2001 [5], concerning Special Autonomy for Papua Province which states that Papua Province is part of NKRI which uses "Sang Merah Putih" Flag as National
Flag and "Indonesia Raya" as National Anthem. This means that Kejora Star flag is only a regional identity and should not stand on sang Merah Putih Flag, if regional symbol (Kejora Star Flag) used as a symbol of struggle for West Papua independence, then this action becomes an act of Treason. In Article 87 of the Criminal Code stated that plot was on the basis of intention. Anshari explained that treason was implied by two factors, namely intention and the beginning of implementation, and more specifically that treason could only be punished if it was associated with certain acts such as State security [6].

\subsection{Free Papua Movement}

The background of OPM emergence, starting from Pro Papua group consisting of educated Papua elites, OPM comes with the aim of liberating Papua and annulling the results of the Act of Free Choice (PEPERA) which is considered to violate New York agreement. OPM was born in Papua region from two Main Factions, First Faction led by Asotek Demotekay who was born in 1963, and second was led by Terianus Arongger who was born in 1964. Their activities were divided into political and military activities. Political activities have aim to garner support abroad, while military activities are carried out in Irian Jaya region through various aggressive actions. However, organizationally, the formation of the Free Papua Movement was part of a joint consensus between elements in Papua, the aim of which was to obtain Papua independence from Indonesia State. Whereas Ideologically OPM is caused by the awareness of Papua people in determining their own destiny along with their own nationalism spirit [7].

Another fact, presented in Suara Merdeka article said that at the time, OPM was controlled by Merdeka Papua leaders who requested and received citizenship from the Netherlands, and called themselves Free Papua Movement (OPM), they were, JE Papare who lives in Apedoorn, Herman Wasiwor who lives in The Hague, Bernadus Tanghama who lives in The Hague, F. Malaiholo, WJ Aringaneng, and OA Dakilwadjir who lives in Hoogeveen [8].

West Papua through its struggle organization always demands independence from Indonesia, but based on political-historical Papua cannot be free because when Netherlands promised independence in 1970 was hindered by New York Agreement (August 15, 1962) so that West Papua fell into Indonesia hands [9]. Among contents of New York agreement, namely, United Nations (UN) is helping Indonesia to provide an opportunity for Occupation of western Papua to make decisions freely, through deliberations with representatives of West Papua population, determining date of opinion determination, formulation of questions in determining the opinion of Papua's regarding their will to remain join Indonesia or separate from Indonesia, and the rights are given to adults, men, and women and held in accordance with international standards.

The existence of OPM has never disappeared, but now mention of OPM has begun to be exiled by the Indonesia Government. Armed group movements such as OPM and 
West Papua National Liberation Army (TNP-PB) are more commonly referred as the Armed Criminal Groups (KKB) [10]. There are many different perceptions, that $\backslash \mathrm{OPM}$ is different from KKB, like Ruben Magai, is a member of 1st Commission of Papua People's Representative Council (DPRP) which states that OPM is different from KKB, OPM is a TPN-PB formed to fight for Papua independence from NKRI while KKB is armed civilian groups are prepared to create chaos, and motives they use are Economic motives. So it can be concluded, although the term OPM has begun to be rarely heard and more often term $\mathrm{KKB}$, but existence of OPM still exists. Giving name about $\mathrm{KKB}$ is only a form of government manipulation for OPM, because in various events involving, KKB always received clarification from OPM members, they said that it was their responsibility (OPM) not $\mathrm{KKB}$, as was the case of attacks that killed 31 people in Nduga District, Papua at the end of 2018 [11].

\subsection{Role and International World Attention}

Existence of the Free Papua Movement which even led to military action has received a lot of world attention, so it is not uncommon to find various Papua independence campaign actions from Indonesia in international world, starting at the regional level, Europe, America, and even at the UN level.

Since before the implementation of the Determination of the Act of free choice -PAPERA, 1969 Papua has actually been given much attention by international world because Papua itself is a former colonial territory which must be completed by process of decolonialization. United States of America (USA) has most significant role in supporting various policies made by Soekarno and Soeharto governments to unite Papua as a former Netherlands East Indies territory into territory of NKRI.

The OPM movement uses diplomatic and foreign paths of politics, is able to invite various supports from several countries, especially those which have their own interests with Papua.

\subsection{OPM vs. Indonesian Government: supported countries}

Fiji, a pacific Asian country, became the founder of the Melanesian Spearhead Group (MSG) and in March 2014 a Fiji musician "Seru Serevi" invited the Pacific island nation to support the Papua independence struggle. Papua New Guinea, as founder of the Melanesian Spearhead Group (MSG) and also neighboring Indonesia, has an unclear attitude towards OPM actions on the ground, and tends to allow OPM activities at the Border.

Vanuatu, as Asia Pacific nation, being the founder of the Melanesian Spearhead Group (MSG) through its Prime Minister Moana Kalosil Carcasses, has condemned Indonesia's policy towards Papua, and is considered a form of colonialism and neo-imperialism.

Senegal, Senegal became one of the African continent countries that supported Papua independence over
Indonesia. Senegal's support is based on Negritudeism, which is solidarity with black race that exists throughout the world. Nauru, at the Summit of the South Pacific Forum in Kiribati, October 2000, the Government of Nauru explicitly supports the independence of Papua over Indonesia [13]. Other countries which were also recorded as supporting Papua's independence were Libya in 1969 and the Free Aceh Movement (GAM) in 1966 [12].

\subsection{Countries that support Indonesia}

Australia, many OPM fled to Australia, such as Herman Wanggai in 2005, but Australian government constructively still supports Indonesia about its sovereignty over Papua, and there are no signs that show the Australian Government's support for OPM. However, on September 2, 2019, Immigration Office of the TPI Sorong class, Papua had deported four Australians who took part in the demonstration of raising the Kejora Star Flag at the Sorong Mayor's office. They are Baxter Tom, Davidson Cheryl Melinda, Hellyer Danielle, and Cobbold Ruth Irene. Although there are some Australians who support the raising of the Kejora Star Flag, it still cannot be concluded that Australia also supports Independence of Papua.

Although OPM opened its representative (campaign office) in city of oxford, which is state of England In 2013, British Federal Government continued to recognize Indonesia Sovereignty and did not oppose Indonesia Government's position and policies towards Papua [13].

Several EU countries such as United Kingdom, Italy, Portugal, Germany, Austria, Denmark, Netherlands, Spain, Sweden, Greece, Belgium and Finland explicitly through visit of the country's ambassadors to Papua in March 2002 fully supported Integrity of Papua into Republic of Indonesia, and support is also given to Indonesia in relation to Special Autonomy in Papua.

United States has always supported Indonesia Government's attitude towards Papua, although on the other hand USA has Special interests relating to existence of PT. Freeport. June 2014 USA Ambassador, Robert O. Blake, Jr. paid a visit to the provinces of Papua and West Papua which marked the increasing cooperation between Indonesia government and USA Government. At the same time, USA Government also reiterated its support for Indonesia and its recognition of Indonesia's territorial integrity of Papua [14]. USA has always provided support to Indonesia in relation to Papua so that United States gained Indonesia support in the Cold War at that time, and kept Indonesia from increasingly close relations with Soviet Union and the Eastern Bloc which also supported Indonesia's military power in seizing West Irian. Another mission owned by the USA is to hinder the development of Communist Ideology in Southeast Asian region. Attitude of USA, helped Indonesia State a lot in pressuring Netherlands, so as not to exert a large influence on Papua through its politics as an occupier at the time.

Existence of USA support for the Indonesia government makes implementation of PEPERA run smoothly, and referendum that has been produced has also not been contested for the next several decades, in line with the success of the largest mining multinational (MNC) 
company in the world from US, Freeport McMoRan, get a long-term concession to exploit the wealth of copper and gold mines in Grassberg, Papua since 1967 [15].

\subsection{International Parliamentarians}

OPM Political Movement is increasingly being expanded by the way they utilize parliamentary channels or parliamentary diplomacy. The technicians that they do seem to be more progressive with efforts of one of characters, namely Benny Wenda. He was once captured by Indonesia security forces and then fled to England. Benny Wenda, activist of the West Papua tribal assembly, has successfully lobbied West minister (House of Commons, House of Common) to launch International Parliamentarians for West Papua so that West Papua's lobbying has now been formed in the British Parliament. Furthermore, Benny Wenda has established a Free Papua Movement (Free Papua Movement -OPM) representative office in Oxford City, England [16]. At the international level, OPM opened its representative (campaign office) in the city of oxford, which is state of United Kingdom on April 28, 2013. Inauguration of office (campaign office) was conducted by Mayor (Lord Mayor) of Oxford, Mohammed Niaz Abbasi and attended by members of Parliament England for East Oxford, Andrew Smith and former Oxford Mayor Elise Benjamin. But presence of Mohammed Niaz Abbasi is by no means a representative of the British (federal) central government. This means that the central government has never expressed its support for Papua independence. Mark Canning the British Ambassador at the time said that Britain fully supported Indonesia's sovereignty over Papua region. The issue of opening an OPM office in city of Oxford does not represent Federal Government in London [17].

But unfortunately, if we look at Federal system as in British Government, Federal (central) state does not have authority and authority on ceremonial issues in its state, except for matters relating to criminal matters and issues relating to foreign countries.

\subsection{The Chaos Caused by OPM}

Various cases allegedly committed by OPM occurred in Indonesia, such as the Attack on the Sinak Police Station, Papua by armed groups by unidentified persons (OTK), the shooting of 8 members of the TNI and civil society causing discomfort in the region. Until 2014, the attack that killed 31 people in Nduga Regency, Papua at the end of 2018, and most recently the riots in Jayapura which killed a TNI member named Sertu Rikson and as many as seven civilians died, allegedly riots were made by OPM supporters in 2019 . In the latest case which occurred in Jayapura in 2019, inviting attention of the United Nations, United Nations High Commissioner for Human Rights (OHCHR) responded to riots that occurred in Papua. UN Human Rights Commissioner Bachelet expressed concern over the escalation of violence that had occurred in Papua. He thinks that the emergence of a conflict rooted in racism is a very serious problem. But on the other hand, Bachelet appreciated the call made by President Joko Widodo along with top State officials related to discrimination and racism received by Papua's, and also the Appeal to ease tensions [18].

\subsection{The Main Reason of Papua for Independence}

When looking at the various problems of Vertical conflict between Indonesia and Papua, it can be understood that this Vertical Conflict occurred because of historical factors in the struggle of the nation, Politics, Social Affairs, and the Government of Indonesia's policy towards Papua.

a. Papua felt that there was no historical connection with Indonesia, while the surrender of Papua to Indonesia was because Papua itself was a former Dutch colony

b. Social inequality between migrants and indigenous Papua

c. Social welfare

d. Indonesia's interest in Irian Jaya

e. The New York One Man One vote agreement, but the Indonesia government was replaced by deliberations (representatives).

The replacement of one man one vote towards deliberation was initiated by Indonesia by forming the Papera Conference Council (DMP) totaling 1025 people who were determined by the Indonesia government not by people choice of Papua themselves, so that since 19 November 1969 Papua was officially integrated with the Republic of Indonesia [19].

\section{CONCLUSION}

Research findings show that vertical conflict between Indonesia and OPM has not abated until 2019 this year. Although the Indonesia government now more often mentions term of KBB rather than OPM on various riot activities in Papua, OPM itself claims to be responsible for several problems that occur. It was clearly stated that the OPM demanded Absolute independence from Indonesia because they felt that the results of the Act of Free Choice (PEPERA) were considered to violate the New York agreement and were invalid, with the reason that the replacement of One Man One Vote towards deliberation had been initiated by Indonesia with Indonesia. form the Papera Conference Council (DMP) without involving and not the choice of the people of Papua. Then historically Papua felt there was no historical connection with Indonesia, while surrender of Papua to Indonesia was because Papua itself was a former Dutch colony.

The results of this study also show how international response to conditions of Papua and Indonesia. For countries that support Papua independence, such as Vanuatu, Senegal, and Fiji assume that Papua has the freedom to fight for its independence and considers Indonesia's policy towards Papua as a form of colonialism and neo-imperialism. As for the supporting countries of Indonesia, especially the UN members stated that Indonesia has absolute sovereignty over Papua as a result of the act of 
[7] Malo, Yuling, Organisasi Papua Merdeka tahun 1960-1969. Yogyakarta : Universitas Santa Dharma, 2017.

[8] Suara Merdeka, “OPM ternyata di kendalikan oleh warga negara Belanda,” april 1969, hlm 1.

To reduce various separatist acts of independent Papua, Indonesia is obliged to act decisively in eradicating separatist members and try as much as possible to break regeneration of Papua separatists. Steps taken can go through the world of Education, namely by providing appropriate education to Papua children, so there are no more Papua people who do not have the spirit of Nationalism towards the Indonesia State. Through Economic Improvement, so that there are no Papua's who feel economically oppressed, through social welfare so that there is no social gap between migrants and natives, and also through various policy formulations towards Papua. Indonesia is obliged to protect every citizen including the people of Papua, so that in event of discriminatory actions against Papua people, State must be present to protect the Papua People. Government is obliged to build mutual trust between Indonesia and Papua, this is necessary if in the future conflict would return again, then conflict resolution can be resolved properly.

\section{REFERENCES}

[1] Tuhana Taufik A, Mengapa Papua Bergolak, Yogyakarta: Gama Global Media, 2001.

[2] Peraturan Pemerintah Republik Indonesia Nomor 77 Tahun 2007 tentang lambang Daerah

[3] Peraturan Pemerintah Pengganti Undang-Undang Republik Indonesia No 1 tahun 2008 tentang perubahan atas UU No 21 Tahun 2001

[4] Yakobus F Dumupa, Berburu keadilan di Papua, Yogyakarta: Pilar Media, 2006.

[5] Undang-Undang Republik Indonesia Nomor 21 tahun 2001 tentang Otonomi Khusus Bagi Provinsi Papua

[6] Anshari, "Delik terhadap keamanan negara (makar) di indonesia (suatu analisis yuridis normatif pada studi kasus sultan hamid II," Jurnal Hukum \& Pembangunan 48 No. 3, 2018, hlm 457-505.
[9] Ngatiyem, Organisasi Papua Merdeka 1964-1998. Surakarta: Fakultas Keguruan dan Ilmu Pendidikan Universitas Sebelas Maret, 2007.

[10]https://www.republika.co.id/berita/kolom/wacana/1 8/12/06/pjad4n440-mendefinisikan-opm-dan-kkb

[11] https://pojoksatu.id/news/beritanasional/2018/12/06/opm-bicara-bukan-kkb-kksbadalah-pejuang-indonesia-kolonial/

[12] KM. Da Silva and Ronald James, Internationalization of Ethnic Conflict, Michigan: Pinter Publishing, 1991.

[13] Elisabeth, Adriana, "Dimensi internasional kasus papua. penelitian bidang politik internasional," P2p LIPI \& Koordinator Tim Kajian Papua 2006 Lipi.

[14] Elly Burhaini Faizal and Nethy Dhrama Somba,"US ambassador visits Papua provinces ," The lokafto Post, June 16, 2014, p. 2.

[15] Nainggolan, Poltak Partogi, “Aktivitas internasional gerakan separatisme Papua," Kajian Vol. 19 No. 3, September 2014, hlm, 781 - 799.

[16] Yanto Soegiarto, "lsolate Benny Wenda and stop the attention seeking," Jakarta Globe, diakses 28 Maret 2014.

[17] Siregar , Hasrul Sani, “Dimensi politik-keamanan organisasi Papua Merdeka (OPM). Seminar Nasional Hukum Volume 2 Nomor 1 Tahun 2016, hlm 369-374.

[18]https://www.cnnindonesia.com/internasional/20190 904165639-106-427529/pbb-angkat-suara-tanggapikerusuhan-di-papua

[19] DR. John. R. G. Djopari, Pemberontakan organisasi Papua Merdeka, Jakarta: PT. Grasindo., 1993, hlm 54. 